\title{
Transport of blue crab larvae by surface currents off Delaware Bay, USA
}

\author{
C. E. Epifanio, A. K. Masse, R. W. Garvine \\ College of Marine Studies, University of Delaware, Lewes, Delaware 19958, USA
}

\begin{abstract}
Weekly abundance of larval blue crabs Callinectes sapidus was determined during late summer (1983 and 1984) at 15 stations on the inner continental shelf within $50 \mathrm{~km}$ of Delaware Bay, USA. Simultaneous measurements of subtidal, surface flow were made at 5 current meter stations within the study area. During both years, larval abundance was greatest during early August when concentrations in excess of 100 zoeae $\mathrm{m}^{-3}$ were commonly observed. By the third week in September, early zoeal stages had disappeared from the water column, and zoeal abundances at all stations were less than 10 zoeae $\mathrm{m}^{-3}$. Results of the current meter measurements provide firm evidence of sustained northward flow of surface water on the inner shelf off Delaware Bay during late summer when $C$. sapidus larvae are common in the plankton. This northward flow occurs on time scales relevant to the rate of larval development of $C$. sapidus and may be important in retaining zoeae near the parent estuary.
\end{abstract}

\section{INTRODUCTION}

Larvae of many species of estuarine crab show behavioral traits that promote retention in estuarine systems (Sulkin 1984). Such behavior may include ontogenetic or tidally rhythmic changes in depth (Cronin 1982, Dittel \& Epifanio 1982, Brookins \& Epifanio $1985)$ that allow the larvae to take advantage of differing flow regimes at various levels in the estuarine water column (Epifanio 1988a). However, not all estuarine species show these types of behavior, and larvae of common taxa such as Callinectes sapidus and $U_{C a}$ spp. are routinely flushed to the inner continental shelf where they become important seasonal components of the meroplankton assemblage (Epifanio 1988b, Epifanio et al. 1988).

Larvae of these estuarine forms may be transported long distances from their parent estuary. Indeed plankton surveys along the east coast of the USA have reported the frequent occurrence of Callinectes spp. zoeae in surface waters of the outer continental shelf in both the Middle Atlantic Bight (Smyth 1979) and the South Atlantic Bight (Nichols \& Keney 1963). Along the inner continental shelf off Chesapeake Bay, $C$. sapidus zoeae have been reported as the most common species of brachyuran larva in late summer (McConaugha et al. 1983).
Because Callinectes sapidus larvae remain near the surface throughout zoeal development (Epifanio 1988b), their transport must be controlled by near-surface flow. For a number of years this presented a conceptual problem, as available data suggested a southward flow of surface water on the inner shelf of the Middle Atlantic Bight during the C. sapidus spawning season (Bumpus 1969). This would result in the advection of large numbers of $C$. sapidus larvae south toward Cape Hatteras where many could be lost to the Gulf Stream before reaching metamorphosis.

Boicourt (1982) proposed that a more complicated circulation field is present during summer in surface waters of the Middle Atlantic Bight and that this field could weaken or reverse the apparent southward displacement of larvae. While acknowledging a persistent southward flow on the outer shelf, Boicourt presented new current meter records from moorings on the inner shelf off Chesapeake Bay. These showed summertime mean currents toward the north in apparent response to the mean northward winds common in summer Boicourt additionally hypothesized that farther inshore, within 10 to $20 \mathrm{~km}$ of the coast, the flow was again southward as a result of a buoyancy-driven coastal current produced by the surface outflow of low salinity water from major estuaries such as Chesapeake and Delaware Bays. Thus, while most larvae would initially 
be swept south in the narrow coastal current, those that were later dispersed seaward would become entrained in the water flowing northward along the inner shelf, and so might remain near their parent estuary.

In the present paper we provide results of a 2 yr study involving simultaneous measurements of: (1) larval Callinectes sapidus distributions and (2) subtidal, surface flow on the inner continental shelf adjacent to Delaware Bay. Because results of earlier work indicated that peak spawning activity of C. sapidus occurs in the bay mouth in late July and early August (Epifanio et al. 1984), measurements were restricted to the late-summer period.

\section{METHODS}

Measurement of currents. Current meter data from 5 moorings on the inner shelf near Delaware Bay were used in the analysis (Fig. 1a). Records from our own Moorings $\mathrm{C}$ and D were obtained during 1983, while records from our Mooring $E$, as well as those from Moorings F and G of the National Ocean Service, were obtained during 1984. All records correspond to the near surface with instrument depths of $5 \mathrm{~m}$ at $\mathrm{C}, \mathrm{D}$, and
$\mathrm{E}$, of $7 \mathrm{~m}$ at $F$, and of $4 \mathrm{~m}$ at $\mathrm{G}$. Vector-averaged values of current were obtained at $0.5 \mathrm{~h}$ intervals so that contamination by surface gravity waves was minimal. The raw current data were subjected to a $40 \mathrm{~h}$ Lanczos low pass filter to remove tidal and higher frequency fluctuations while preserving the subtidal frequency fluctuations that most affect the drift of larvae.

Larval collection. The collection area was located near the mouth of Delaware Bay (Fig. 1b) and consisted of 3 regions - Bay Mouth ( 3 stations), Coastal Current (4 stations), and Inner Shelf (8 stations). In 1983 and 1984, weekly surface collections $(0.5 \mathrm{~m}$ to $1 \mathrm{~m})$ were made at each of the 15 stations from late July through mid-September. Sampling was conducted during daylight from a $7 \mathrm{~m}$ boat equipped with LORAN-C navigation. Two cruises (on consecutive days) were required to reach all 15 stations each week. Collecting gear consisted of a $0.5 \mathrm{~m}$ plankton net fitted with $243 \mu \mathrm{m}$ mesh and a General Oceanics flow meter.

Preservation and analysis of plankton. Samples from all collections were preserved on board in $4 \%$ formaldehyde in seawater. After a minimum of $1 \mathrm{wk}$ in formaldehyde, samples were transferred to $70 \%$ ethanol. Samples were subdivided with a Folsom plankton splitter (Dittel \& Epifanio 1982), and one randomly chosen
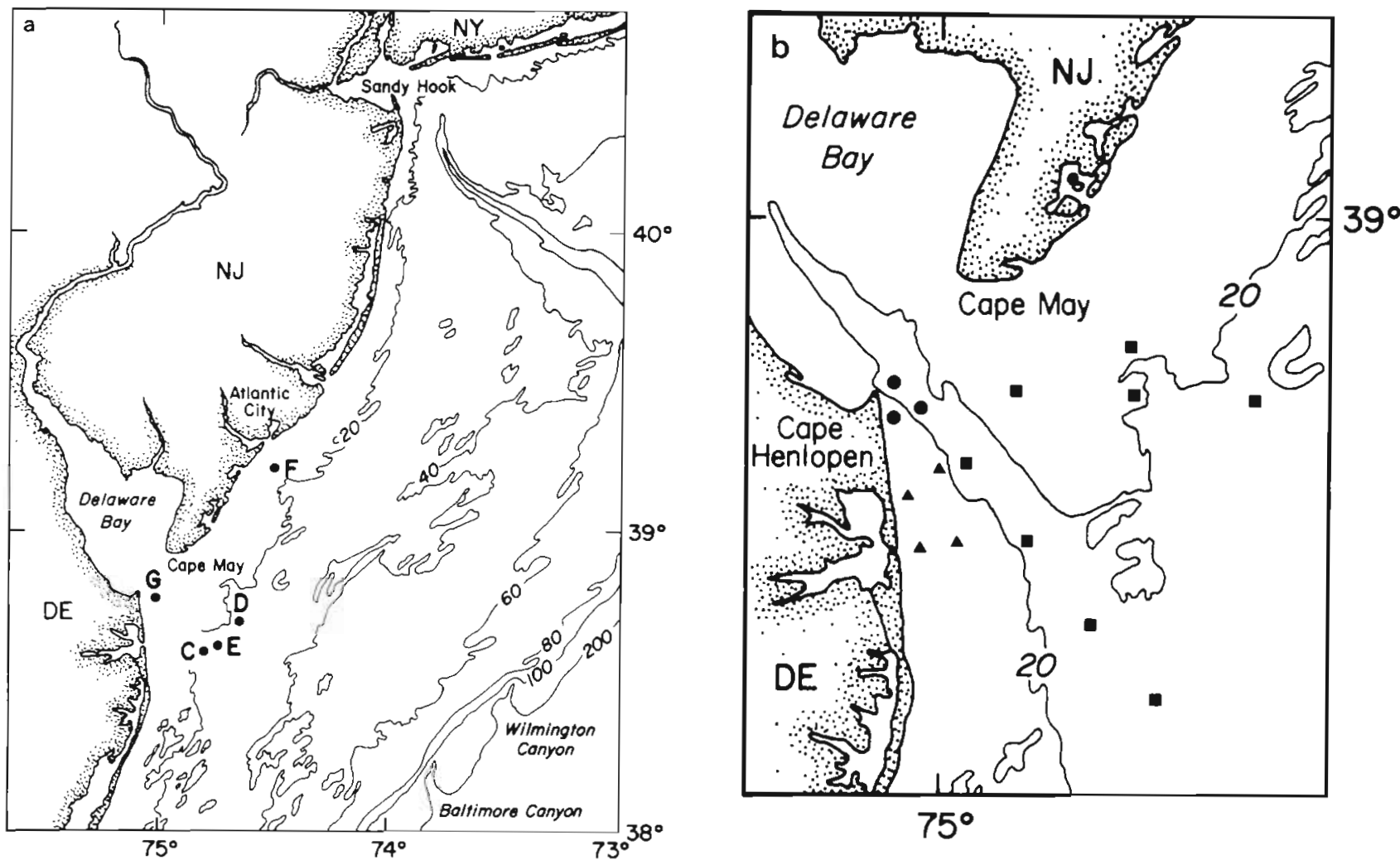

Fig. 1. Locations of (a) moored current meters and (b) crab larval collections near Delaware Bay, USA. Surface currents were measured coincident with larval collections in August/September, 1983 and 1984. Isobaths are in meters. Larval collection stations were in 3 separate regions: (O) bay mouth; $(\boldsymbol{\Delta})$, coastal current; $(\boldsymbol{\square})$ inner shelf 
subsample was analysed for each collection. Callinecter sapidus larvae were identified to stage using a key to the decapod larvae of the region (Sandifer 1972).

\section{RESULTS}

\section{Surface currents}

Two formats are used in the presentation of surface current data from 1983 and 1984. Arrows show the direction and speed of the mean current for the period of measurement at each mooring, and progressive vector diagrams represent the same information for a subset of these moorings (Figs. 2, 3 and 4). A progressive vector diagram is the integral of the low-pass filtered current vector over time, beginning at the starting time of each record. Such a diagram has the dimensions of length or displacement. In Figs. 2, 3 and 4 we plot these progressive vector diagrams using the same spatial

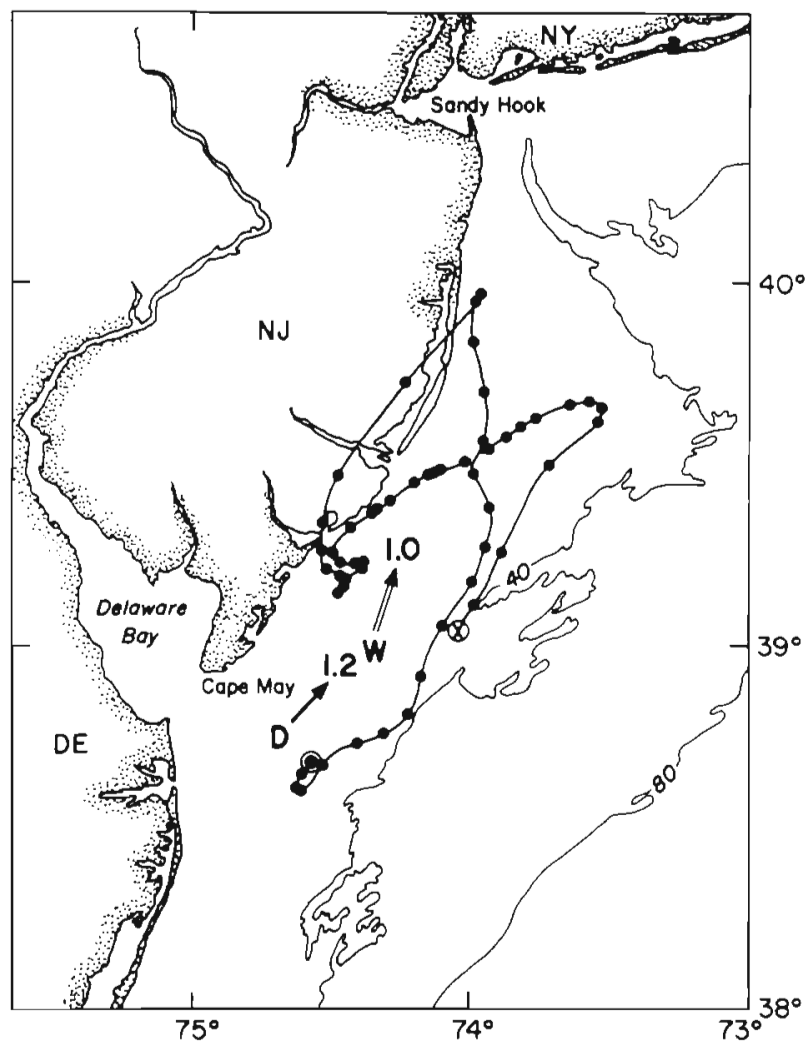

Fig. 2. Progressive vector diagram for low-pass filtered, surface current records from summer 1983 at Mooring $C$ on the inner continental shelf off Delaware Bay, USA. Closed circles along each diagram denote $1 \mathrm{~d}$ increments in time. Mean current vector for the entire period is shown at each mooring with directions along the arrow and speed $\left(\mathrm{cm} \mathrm{s}^{-1}\right)$ given at the arrow point. The mean wind vector, measured at Atlantic City (location shown in Fig. 4), is also shown and labelled ' $W$ ' with wind speed $\left(\mathrm{m} \mathrm{s}^{-1}\right)$ at the point of the arrow

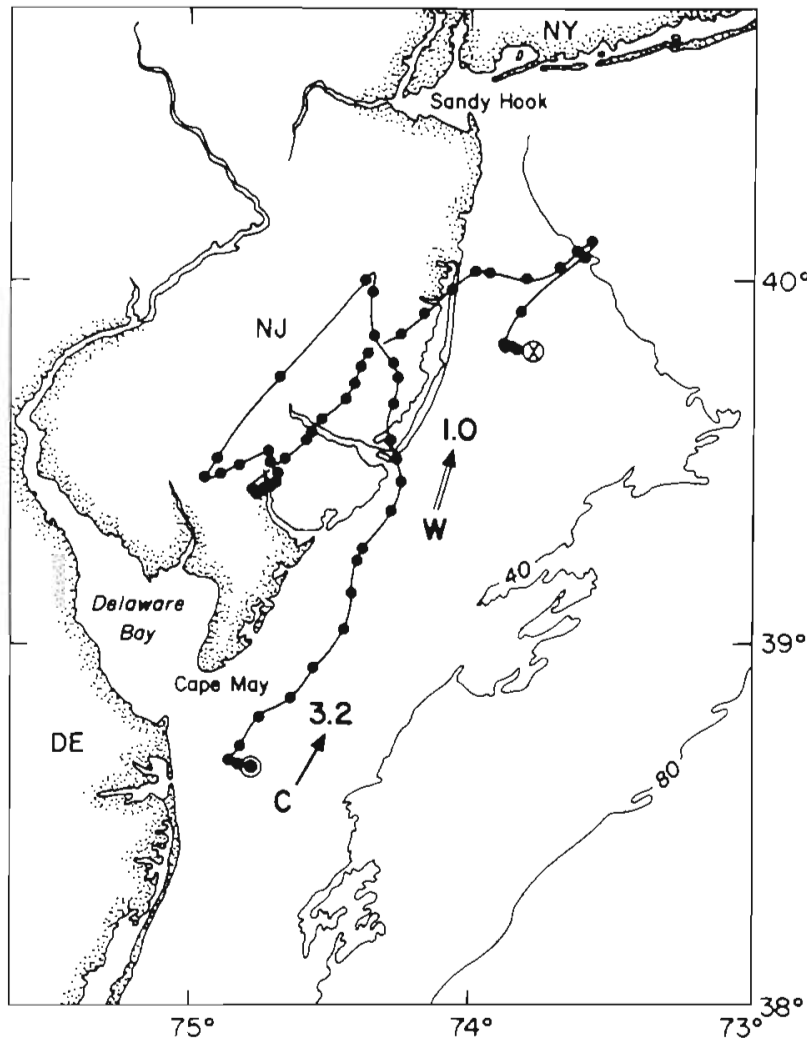

Fig. 3. Progressive vector diagram for low-pass filtered, surface current records from summer 1983 at Mooring D on the inner continental shelf off Delaware Bay, USA. Closed circles along each diagram denote $1 \mathrm{~d}$ increments in time. Mean current vector for the entire period is shown at each mooring with directions along the arrow and speed $\left(\mathrm{cm} \mathrm{s}^{-1}\right)$ given at the arrow point. The mean wind vector, measured at Atlantic City (location shown in Fig. 4), is also shown and labelled ' $W$ ' with wind speed $\left(\mathrm{m} \mathrm{s}^{-1}\right)$ at the point of the arrow

scale as the underlying maps of the shoreline and bottom topography. Closed circles appear along these diagrams indicating time at successive intervals of $1 \mathrm{~d}$. New segments are added to the diagram for each day that a current meter is operating. For example, if the current were constant to the north at $1 \mathrm{~km} \mathrm{~d}^{-1}$ during the first day of a meter's operation, the corresponding part of the progressive vector diagram would be a $1 \mathrm{~km}$ straight-line segment toward the north from the mooring; that segment would terminate at a closed circle. Then, if the second day's flow at the meter were $1.5 \mathrm{~km}$ $\mathrm{d}^{-1}$ to the northwest, a $1.5 \mathrm{~km}$ straight-line segment would be drawn from the termination of the first segment toward the northwest; this segment would terminate at a second closed circle. The vector mean current for those $2 \mathrm{~d}$ would have the same direction as a vector drawn from the mooring to the second closed circle and would have the speed of that vector's length divided by the elapsed time. (In this example the elapsed time would be $2 \mathrm{~d}$.) A vector mean current could be con- 


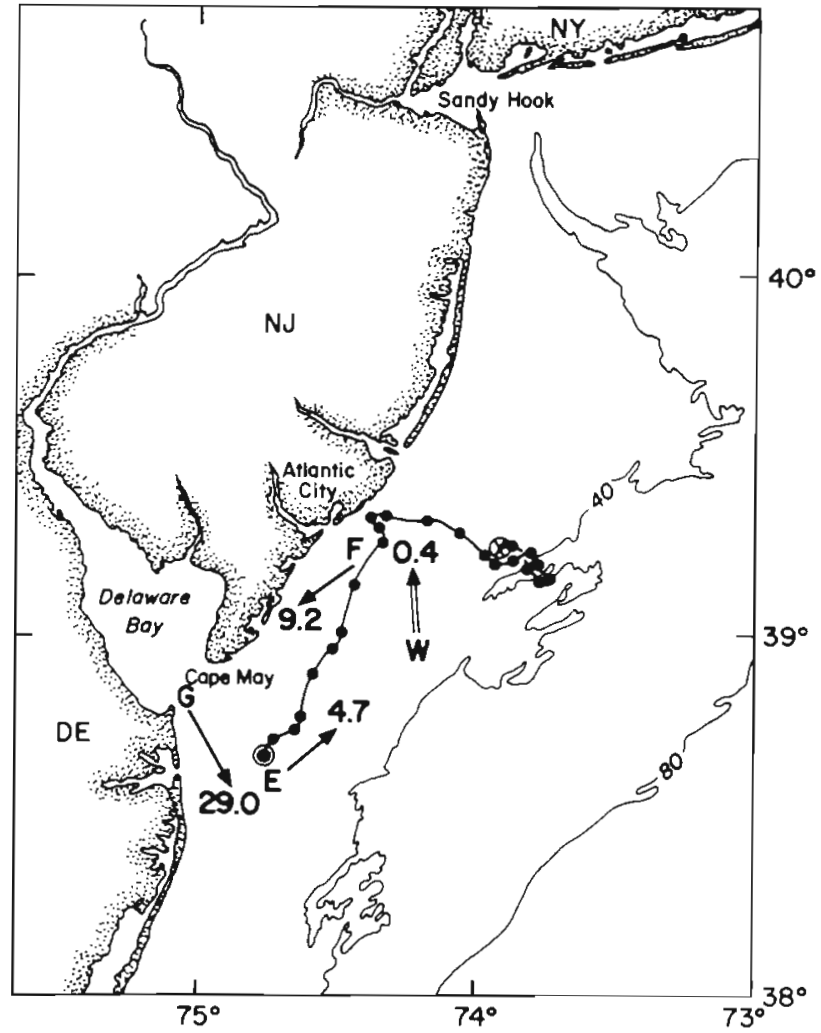

Fig. 4. Progressive vector diagram for low-pass filtered, surface current records from summer 1984 at Mooring $E$ on the inner continental shelf off Delaware Bay, USA. Closed circles along each diagram denote $1 \mathrm{~d}$ increments in time. Mean current vectors for the entire period are shown at Moorings $E$, $F$, and $G$ with directions along the arrow and speed $\left(\mathrm{cm} \mathrm{s}^{-1}\right)$ given at the arrow point. The mean wind vector, measured at Atlantic City, is also shown and labelled ' $W$ ' with wind speed $\left(\mathrm{m} \mathrm{s}^{-1}\right)$ at the point of the arrow

structed accordingly for any number of days that the current meter was operating. Hence the name, 'progressive vector', as the current vector 'progresses' along the diagram with increasing time.

A progressive vector diagram provides a visual sense of temporal variability in current at a fixed point in space. Thus, the character of a progressive vector diagram is Eulerian, not Lagrangian, despite the use of displacement as a variable. If at each instant of time the current field were the same throughout the entire spatial domain, the diagram would represent a true particle trajectory (a Lagrangian property), but fluid particles generally enter different flow fields once they pass the point of observation.

Progressive vector diagrams for Moorings $\mathrm{C}$ and D span the time of larval collection in 1983, from 26 July to 20 September (Figs. 2 and 3). Mooring $C$ was on the $20 \mathrm{~m}$ isobath on the inner shelf about $30 \mathrm{~km}$ from the bay mouth, while $D$ was near the $30 \mathrm{~m}$ isobath about $43 \mathrm{~km}$ from the mouth. The mean current for the $46 \mathrm{~d}$ record was $3.2 \mathrm{~cm} \mathrm{~s}^{-1}$ alongshore toward the northeast at Mooring $\mathrm{C}$ and of about the same direction but slower speed, $1.2 \mathrm{~cm} \mathrm{~s}^{-1}$, at Mooring D. Thus, both mean currents were opposite the direction of the annual climatic mean, which is toward the southwest (Beardsley et al. 1976). Nevertheless, these northeastward currents were consistent with the mean wind vector for the study period, which was ca $1.0 \mathrm{~m} \mathrm{~s}^{-1}$ toward the northeast (Fig. 3). The progressive vector diagrams indicate large variability in the subtidal frequency currents with time, but also show considerable spatial coherence between the 2 moorings. The flow was first to the north for about $18 \mathrm{~d}$ at both moorings with an accumulated displacement of about $160 \mathrm{~km}$ in that direction. (However, the divergence between these displacements and true particle trajectories is clear, in that the diagram for Mooring C overlies inland areas of the map late in this period.) Thereafter, both currents turned rapidly toward the southwest for $3 \mathrm{~d}$, then became nearly slack for $10 \mathrm{~d}$. This was followed by $17 \mathrm{~d}$ of northeastward movement and a final week of southwestward flow. The potential for rapid excursions alongshelf is clear from these diagrams. A particular parcel of water could move as much as $100 \mathrm{~km}$ alongshelf in either direction between weekly larval collections.

During the larval sampling period in 1984, the mean current at Mooring $E$ (nearly at the site of Mooring $C$ in 1983) was similar in speed and direction to that at $C$ in 1983, northeastward at $4.7 \mathrm{~cm} \mathrm{~s}^{-1}$, and the progressive vector diagram is likewise similar (Fig. 4). The vector mean wind, northeast at $0.36 \mathrm{~m} \mathrm{~s}^{-1}$, was consistent. Thus, the inner shelf flow appeared to be similar to 1983, again reversed from the direction of the climatic mean.

Progressive vector diagrams for $F$ and $G$ are not shown because there was little variability in their direction with time and because the associated displacements for the period would have reached well beyond the map boundaries $(580 \mathrm{~km}$ for G). During the sampling period in 1984, mean currents at both sites were strong to the south, $9.2 \mathrm{~cm} \mathrm{~s}^{-1}$ off the New Jersey coast at $F$ and $29.0 \mathrm{~cm} \mathrm{~s}^{-1}$ off the Delaware coast at $\mathrm{G}$. While one expects this strong southward current at $G$ near the mouth of Delaware Bay, that off the New Jersey coast is more surprising. Both currents mark a decidedly different summer flow regime from that of the inner shelf at E and are associated with the buoyancy-driven coastal current found within 10 to $20 \mathrm{~km}$ of the shore. The current is stronger at $\mathrm{G}$ because low density (low salinity) water is added locally from Delaware Bay, whereas at $F$ the principal source is far to the north in the Hudson River outflow.

Our summertime surface current data are thus consistent with the hypothesis of Boicourt (1982). A local 
inshore coastal current from the shore out to about $20 \mathrm{~km}$ conveys water persistently and rapidly southward, while farther offshore the currents are often reversed to the north by the prevailing northward winds of summer.

\section{Larval abundance}

There was no temporal coherence in larval abundance in any of the sampling regions, i. e. knowledge of abundance in any sampling region did not allow prediction of abundance in that region or any other region during the following week (Table 1). In addition there appeared to be a great deal of spatial patchiness in the distribution of larvae, as standard deviations were generally equal to or greater than mean values for abundance in each of the sampling regions. Mean abundance in all 3 regions was highest in early August, and patches with concentrations greater than 10 larvae $\mathrm{m}^{-3}$ were always dominated by zoea stages I and II. These early stages were collected as far as $50 \mathrm{~km}$ from the spawning area in the mouth of Delaware Bay. Zoea stage I was most abundant in each region throughout August, but the relative abundance of stages II to VIII increased after mid-August, especially in the Inner Shelf Region. The relative abundance of advanced zoeal stages was highest in mid-September when absolute larval abundance was lowest.

\section{DISCUSSION}

Results of our 2 yr investigation showed little interannual variation in the abundance of Callinectes sapidus zoeae in surface waters off Delaware Bay. During both years maximum concentrations of stages I and II occurred in early August. This coincided with the known period of peak spawning activity in the mouth of Delaware Bay (Dittel \& Epifanio 1982, Epifanio et al. 1984). The relative abundance of advanced stages was greatest in the sampling region farthest from shore. These advanced stages were first apparent in midAugust. This corresponds well with laboratory-derived development rates of C. sapidus zoeae (Sulkin 1978) Spawning activity in the area had effectively ceased by mid-September, as the abundance of zoea stages I and II fell to less than 1.0 larva $\mathrm{m}^{-3}$ in the nearshore sampling regions. Farther offshore in the Inner Shelf sampling region the relative abundance of advanced stages reached its seasonal maximum in mid-September. These results are largely in accord with those of an earlier investigation off the mouth of Chesapeake Bay (McConaugha et al. 1983).

In general, there was little week-to-week correlation in the spatial distribution of zoeae, thus suggesting that the frequency of larval collections was insufficient to resolve the details of zoeal transport. An inspection of the progressive vector diagrams indicates that the distance a parcel of surface water would have travelled during any week of the study was greater than the radius of the study area. Thus sampling on a daily basis would have been required to have had any chance of relating the observed zoeal distributions to the coincidentiy measured surface currents.

Nevertheless, our results provide the first evidence of persistent northward flow of surface water on the inner continental shelf off Delaware Bay during late summer when Callinectes sapidus larvae are common in the plankton. Furthermore, this northward flow occurs on time scales relevant to the rate of larval development of C. sapidus. For example the first episode of northward flow at current meter Mooring D in 1983 lasted $18 \mathrm{~d}$ compared to a laboratory determination of about $30 \mathrm{~d}$ of zoeal development of C. sapidus at $25^{\circ} \mathrm{C}$ (Sulkin 1978). A patch of stage I zoeae located in surface water at that current meter on July 26 would have been carried ca $160 \mathrm{~km}$ north of the study area and would have reached zoea stage IV or $\mathrm{V}$ before beginning any movement back to the south. During 1984 a similar patch at nearby Mooring $E$ would have travelled ca $70 \mathrm{~km} \mathrm{~N}$ before beginning any southward movement.

Of course any explanation of dispersal in Callinectes sapidus must include the initial movement of stage I zoeae out of the estuarine mouth where hatching occurs. Much of this flow in Delaware Bay appears to occur as a southward coastal current regardless of season (Pape \& Garvine 1982). Our data suggest that this results in rapid alongshore transport of many newly hatched zoeae, as stage I larvae were very common throughout August in the Coastal Current sampling region. While some of these larvae are undoubtedly carried long distances to the south where they may be recruited into other estuaries, others must be entrained, through mixing, in the northward-flowing surface current farther offshore. This provides a mechanism for retention of Delaware Bay larvae near the parent estuary. While the main surface flow out of Delaware Bay joins the coastal current to the south, the surface outflow from the eastern side of the bay may be carried offshore of the coastal current and there mix directly with water on the inner shelf (Pape \& Garvine 1982). This may explain the common occurrence of zoea stage I larvae at stations in the Inner Shelf sampling region during the peak spawning period in early August.

In summary the physical and biological results of the present study corroborate the recent hypotheses (Johnson 1985, Sulkin \& Epifanio 1986) concerning dispersal of blue crab zoeae in the Middle Atlantic Bight. Based on our results, there can be no question that early stage 
Table 1 Callinectes sapidus. Mean abundance of zoea larvae near Delaware Bay, USA. BM: bay mouth; CC: coastal current $(<15 \mathrm{~km}$ from shore); IS: inner shelf (>15 km from shore). Values in parentheses are standard deviations. August-September, $1983 \& 1984$

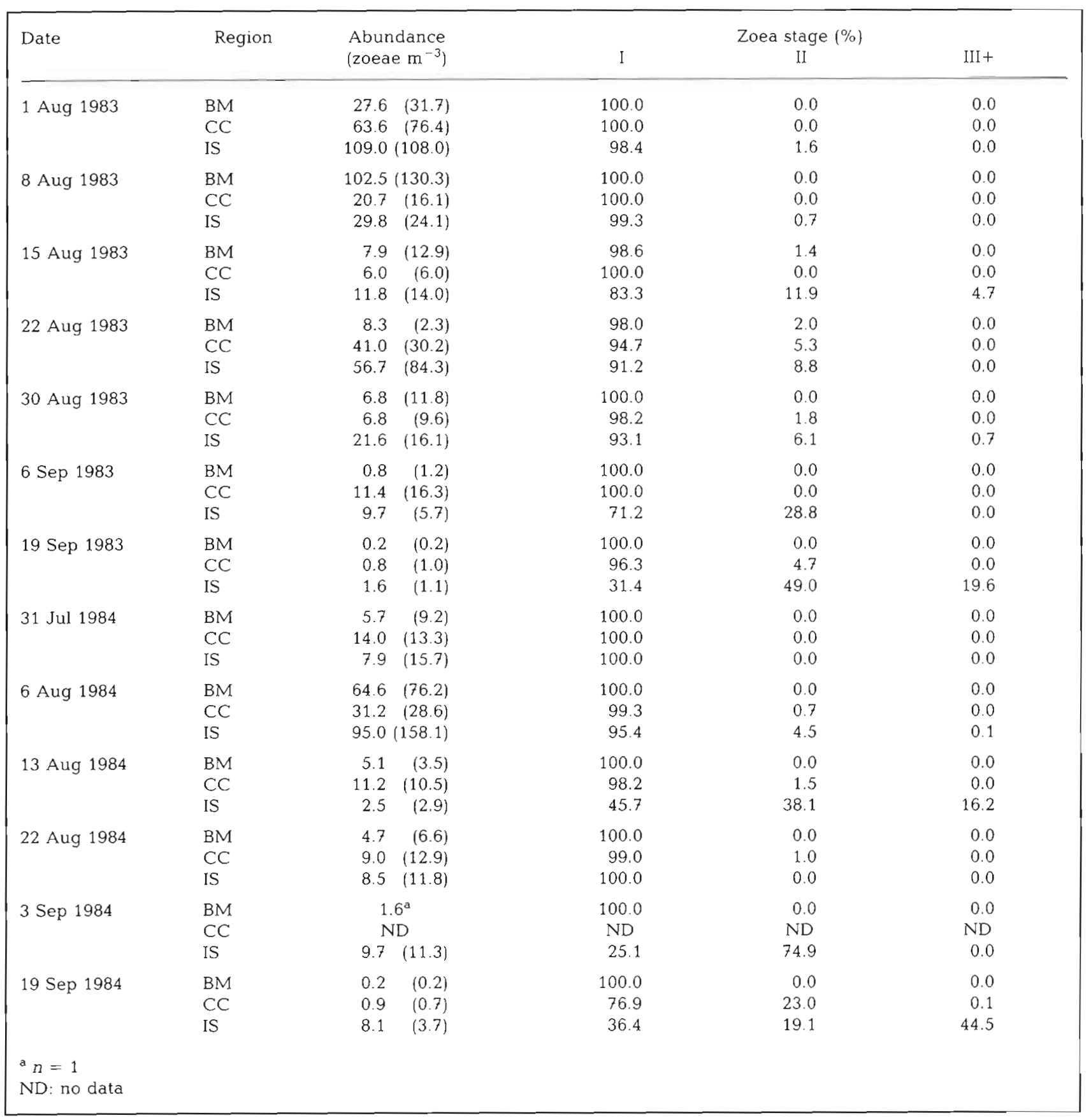

larvae are flushed rapidly from large estuaries such as Delaware Bay and that substantial numbers of these larvae are carried far to the south in the coastal current. But our results show that large numbers of zoeae are mixed to the inner shelf where wind-driven surface flow can carry the larvae to the north on scales of hundreds of kilometers. In the absence of this northward flow on the inner shelf, retention of some zoeae near Delaware Bay might be accomplished by turbulent mixing in the near-bay environment, but the majority of larvae spawned in the bay would be carried away to the south. Thus the idea that retention of zoeae near Delaware Bay is ultimately dependent on the direction, strength, and duration of wind over the inner shelf in August is correct (Epifanio et al. 1984). In addition our data have shown great potential for both 
northward and southward transport from estuaries such as the Delaware. Furthermore, the time scale of such transport in either direction coincides with the duration of larval development in Callinectes sapidus. Thus, the exchange of larvae among the estuaries in the Middle Artlantic Bight must occur on a very frequent basis, and the disparate adult assemblages in the estuaries of the bight must constitute one large interbreeding population.

Acknowledgements. This research was sponsored by NOAA Office of Sea Grant, Department of Commerce under Grant No. NA85AA-D-SG033 and by the National Science Foundation under Grant OCE-8300011. Big John Ellsworth and Dave Fredman Fredrick conducted most of the field collections. Karl Brookins, David Goshorn, Kathleen Little, and Peter Rowe sorted and analysed the plankton samples.

\section{LITERATURE CITED}

Beardsley, R. C., Boicourt, W. C., Hansen, D. V. (1976). Physical oceanography of the Middle Atlantic Bight. Limnol Oceanogr. Spec. Symp. 2: 20-34

Boicourt, W. C. (1982). Estuarine larval retention mechanisms on two scales. In: Kennedy, V. (ed.) Estuarine comparisons Academic Press, New York, p. 445-458

Brookins, K. G., Epifanio, C. E. (1985). Abundance of brachyuran larvae in a small coastal inlet over six consecutive tidal cycles. Estuaries 8: 60-67

Bumpus, D. R. (1969). Reversals in the surface drift in the Middle Atlantic Bight area. Deep Sea Res. Suppl. 16: $17-23$

Cronin, T.W. (1982). Estuarine retention of larvae of the crab Rhithropanopeus harrisii. Estuar. coast. Shelf Sci. 14 $28-40$

Dittel, A.I., Epifanio, C.E. (1982). Seasonal abundance and vertical distribution of crab in Delaware Bay. Estuaries 5: $197-202$

This article was submitted to the editor
Epifanio, C.E. (1988a). Transport of invertebrate larvae between estuaries and the continental shelf. Am. Fish. Soc Symp. 3: 104-114

Epifanio, C. E. (1988b). Dispersal strategies of two species of swimming crab on the continental shelf adjacent to Delaware Bay. Mar. Ecol. Prog. Ser. 49: 243-248

Epifanio, C. E., Little, K. T., Rowe, P. M. (1988). Dispersal and recruitment of fiddler crab larvae in the Delaware River estuary. Mar. Ecol. Prog. Ser. 43: 181-188

Epifanio, C. E., Valenti, C. C., Pembroke, A. E. (1984). Dispersal and recruitment of blue crab larvae in the Delaware Bay, USA. Estuar. coast. Shelf. Sci. 18: 1-12

Johnson, D.R. (1985). Wind-forced dispersion of blue crab larvae in the Middle Atlantic Bight. Cont. Shelf Res. 4: 733-745

McConaugha, J.R., Johnson, D. F., Provenzano, A. J., Maris, R. C. (1983). Seasonal distribution of larvae of Callinectes sapidus (Crustacea: Decapodal in the waters adjacent to Chesapeake Bay. J. Crust. Biol. 3: 582-591

Nichols, P. R., Keney, P. M. (1963). Crab larvae (Callinectes), in plankton collections from cruises of M/V Theodore $N$. Gill, South Atlantic Coast of the United States, 1953-54. U. S. Fish Wildl. Serv., Spec. Sci. Rep. Fish. 448, p. 1-14

Pape, E. H. III, Garvine, R. W. (1982). The subtidal circulation in Delaware Bay and adjacent shelf waters. J. geogphys. Res. 87: 7955-7970

Sandifer, P.A. (1972). Morphology and ecology of Chesapeake Bay decapod crustacean larvae. Doctoral dissertation, University of Virginia, Charlottesville

Smyth, P. O. (1979). Callinectes (Decapoda: Portunidae) larvae in the Middle Atlantic Bight, 1975-1977. Fish. Bull. U. S. 78: 251-265

Sulkin, S.D. (1978). Nutritional requirements during larval development of the portunid crab, Callinectes sapidus. J. exp. mar. Biol. Ecol. 20: 119-135

Sulkin, S. D. (1984). Behavioral basis of depth regulation in the larvae of brachyuran crabs. Mar. Ecol. Prog. Ser. 15 $181-205$

Sulkin, S. D., Epifanio (1986). A conceptual model for recruitment of the blue crab, Callinectes sapidus Rathbun, to estuaries of the Middle Atlantic Bight. Can. Spec. Pub Fish. Aquat. Sci. 92: 117-123

Manuscript first received: September 19, 1988

Revised version accepted: March 8, 1989 